\title{
Vitalization Strategy in the Disadvantageous Areas for Regional-Specific Label Agricultural Products: Prospects for Structuring an Affluent Rural Society and Sustainable Livelihood
}

\author{
Hu Bai (Ehime University)
}

This paper is aimed both to examine the effects of developing regional-specific label agricultural (RSLA) products in the development of regional agriculture, and to identify the possibility and conditions to vitalize the disadvantageous areas for RSLA products, in order to determine the effective policy measures for structuring an affluent rural society and sustainable livelihood for rural residents.

The main findings can be summarized as follows. 1) Efforts aimed to increase RSLA products have brought innovative effects in agricultural development and vitalizing regional economy in about $20 \%$ of the Japanese rural areas. This also implies that the measures rather than RSLA product strategy are necessary for the remaining about $80 \%$ of the areas. 2) Case studies from three citrus areas suggest that the improvement in production condi- tions and farmers' incomes is becoming the critical factor of vitalizing rural and regional economy. 3) An analysis of project composition from 1,795 municipalities indicates that a lot of measures aimed to vitalize regional economy and rural society, rather than RSLA product strategy, have been planned or being practiced. These measures should be used effectively and selected carefully according to local conditions.

Based on these results, this paper suggests four measures for vitalizing rural society and regional economy. These are: 1 ) to promote the improvement in production conditions, 2) to increase farmers' incomes by improving the performance of local agricultural cooperatives, 3) to introduce farm income improvement policy, and 4) to promote the settlement in handicapped areas by subsidizing residents and improving the rural landscape.

\section{1. はじめに}

本報告に与えられた課題は, 農林水産物・食品ブ ランドの形成が困難な地域で農業・農村の活性化を どう図るかについて検討することである。 そもそも 何が地域ブランドで, 何が地域ブランドでないかに ついての線引き自体には多くの難点がある. 農産物 はもとより地域性を有し, 同一品種で産地の自然条

\footnotetext{
* 愛媛大学
}

件や農法等の違いによって差が生じ, 地域特産品と して形成される場合があるし，そういった差がなく ても生産量の大きさや個性的なマーケティング等に よって様々な産地ブランドを形成してきた歴史もあ る. 地域ブランドの形成が困難かどうかというのも, それまでの状態のみを指す極めて限定的な意味しか 持たない. そこで本報告では, 地域ブランドの動き を一定の幅を持って捉えるとともに,「地域ブランド 形成の困難な産地」についても, 現段階でブランド 産品を持たない産地やブランド発掘育成中産地のほ 
か, ブランド産品があるものの基幹作目をカバーす るほどの品目に当たらず，その取組で農業・農村の 活性化を図るのが困難と見られる地域等を想定す る. 後者をブランド形成の困難な産地とみてよいか どうかについて吟味の余地もあるが, 少なくとも地 域農業を牽引する産品の発掘育成に苦悩している点 でブランドを持たない産地とほぼ同様の課題を抱え ていると言える.これらの産地, こういった産地を 抱える地域の存続・活性化をどう図るかが, いま, 重 要な地域問題または政策課題として問われている.

図 1 （a）は,「食」と「農」と「地域」に関わる ブランド化の取組を取り上げた雑誌記事の変化を示 している. 1980 年代に出現し始めた関連記事は 90 年代半ばから急速に増え, 今や年間百数十件に上る 注目の話題になっている. しかし他方では, 地域ブ ランドへの関心が急上昇し始めた頃から農家所得は 下降傾向を辿り，その動きと連動するかのように農 林漁業者の生活満足度も急速に低下してきている (図 1 (b))。その理由としては, 90 年代中期頃から 徐々に進行してきた農業の交易条件の悪化に近年の 燃料・資材高, 世界同時不況が重なり, 農村経済や
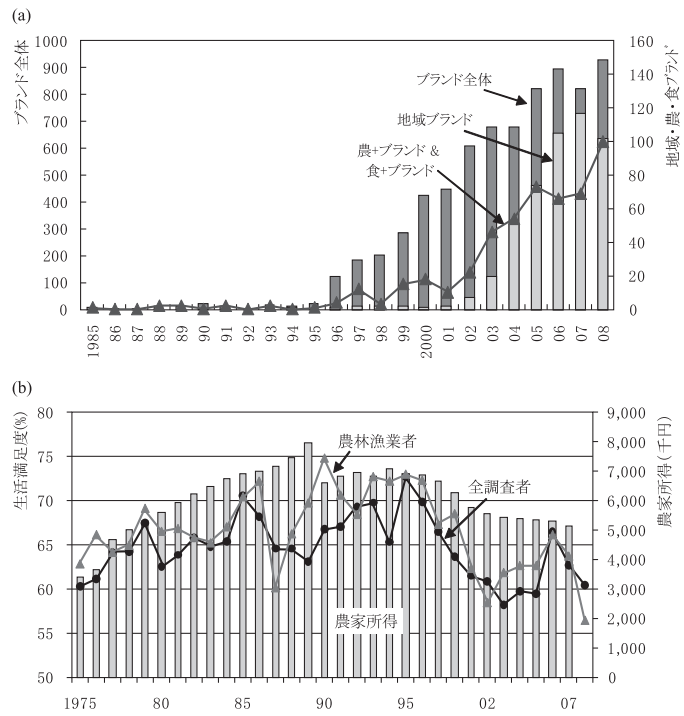

図 1.（a）ブランド関連雑誌記事数の変化，（b）農 家所得と農林漁業者の生活満足度の変化.

注 : ブランド関連記事は国会図書館雑誌記事索引, 生活満 足度は内閣府「国民生活に関する世論調査」, 農家所得 は農林水産省「農家経済調査」「農業経営統計調査」に より筆者作成.
これを基盤とする地域経済は疲弊してきたからと考 えられる. 地域ブランド形成の取組はこうした状況 を打開するための手法として注目されているなら ば，疲弊する地域経済や農村社会を活性化するため にそれがどのような有効性を持つかを当然問わね将 ならないし, 地域ブランドを持たない産地, こういっ た産地を抱える地域の存続・活性化をどう図るかに ついても, 地域ブランドへの高い注目度に対置する 問題として検討されなければならない．本報告では これらの点を検証することにより，食と農を軸とす る豊かな地域社会と穏やかな暮らしの形成について 展望を行う。

\section{2. 地域ブランドの有効性〜地域農業の視点から〜}

\section{（1）地域ブランドと地域農業}

地域ブランドに期待する効果として, 2008 年に公 表した農林水産省報告書「農林水産物・食品の地域 ブランドの確立に向けて」（以下，「WG 報告」と略 称）では，生産者側にとっては「マーケティング力 の向上とそれに伴う収益の向上による地域の農林業 の発展」,「地域経済の活性化」「地域コミュニティ の再生」, 消費者側にとっては「選択の幅の増加」, 「食文化の発展に寄与」,「地域への関心の高まり」を 挙げている. しかし, 地域ブランドの取組がこういっ た「地域」効果に結び付くかどうかは，関係品目が どこまで地域の基幹作目をカバーし，地域農業を率 引する力を持っているかどうかによると考える.

この点については, 地域団体商標の都道府県別登 録状況と各地の特徵的な農産物 ${ }^{1 ）}$ との対応関係を通 してみることができる。地域団体商標制度は「地域 ブランドの育成に資するため」に制定されたもので, 2006 年に施行されて以来, 農林水産行政や地域農業 の方向付けに多大な影響を及ぼしてきたことが周知 の通りである. 2009 年 2 月現在, 41 都道府県からの 415 品目が地域ブランドとして登録されている（特 許庁)。 そのうち, 農林水産物・食品関連品目が全体 の $55 \%$ を占め, 地域ブランド形成の取組において 「農」と「食」が大きな存在感を示している.

地域農業を牽引する力強さを示す特徵的な農産物 の該当品目数は 58 件, 農林水産 1 次産品登録件数の $36 \%$ ，食品を含む登録件数の $26 \%$ ，各地域特徵的な 農産物延べ数の $18 \%$ をカバーしている. 希少性ある ブランド品からすれば低い数值とは言えない. しか 


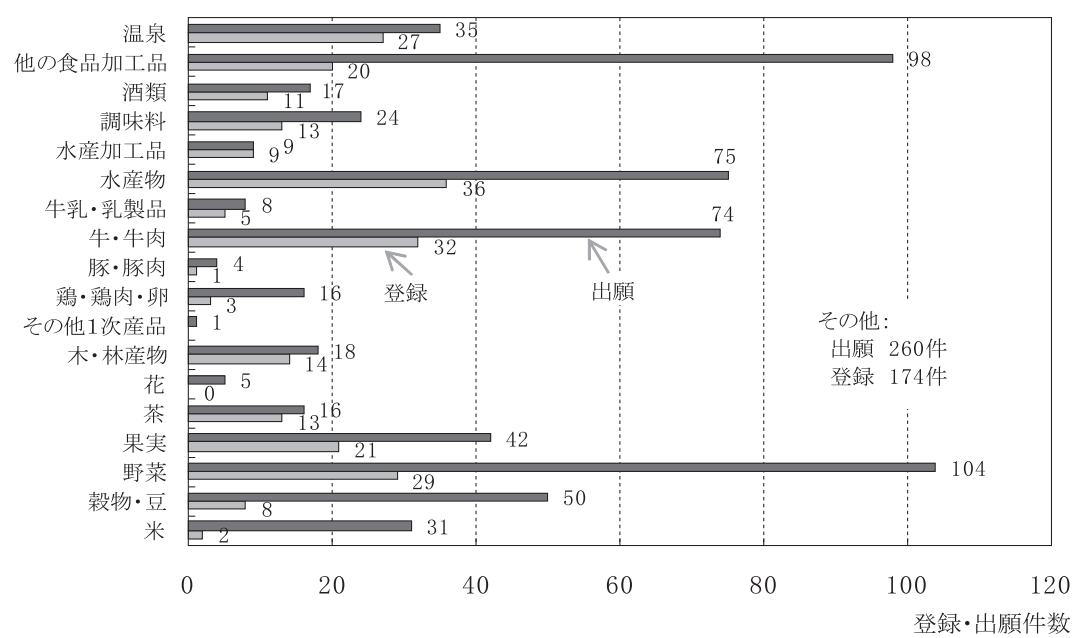

図 2. 地域団体商標登録・出願品目の構成

し京都, 和歌山, 鹿児島諸県を除けば特徵的な農産 物のカバー率が概して低く, 該当しない都府県も 21 に上る.このことは, 登録件数の品目別構成にも現 れている（図 2). 農林水産 1 次産品の $42 \%$ は水産物 や牛・牛肉等所得弾力性の高い品目が占め, 基幹作 物の米関連品目なら富山県「黒部米」と「京都米」 のみである. 政策奨励作物の麦, 大豆については味 増・麺類等加工品があるものの, 1 次産品の登録実 績が皆無である. 地域ブランドが注目されている中 で, 基幹作目の振興をどう図るかがほぼすべての地 域で課題として残る.

この点をもう少し幅を持って評価するには, 登録 品目だけでなく出願中品目を含めてみる必要があ る. 図 2 に示すように, 2009 年 1 月現在, 登録済み を除く出願品目が 450 件ある. 農林水産 1 次産品に おいて野菜は 75 件で最も多く, その次に芋, そばを 含吉穀物・豆類と牛・牛肉はそれぞれ 42 件, 水産物 は 39 件，米は 29 件，果実は 21 件と並ぶ. 登録品目 に比べて基幹作目のブランド化を目指す動きが顕著 に現れている. しかし, 仮にすべての出願品が登録 したとしても, 基幹作目の振興をどう図るかが依然, 課題として残る. これは, 登録と出願件数の倍率差 が最も大きい米を取ってみれば明白である. 北海道, 山形, 新潟諸県のように米を県域ブランドとして確 立しょうとしている地域もあるが, ほとんどの場合, 出願があったと言ってもごく限られた地域で生産さ れる地域特産品である. 京都以西の西日本での出願
実績は「丹波ひかみ米」と「東条産山田錦」のみで ある。

しかし, 地域ブランドの取組は地域団体商標関連 のほか, ナショナル・ブランド $(\mathrm{NB})$ や企業のプラ イベートブランド $(\mathrm{PB})$ 等もあり ${ }^{2)}$ ，そういったも のを含めてブランド関連取組がどこまで農業, 農村 地域に影響を与えているかが 1 つの注目点になる. 表 1 は, 2000 年農業センサス調査でブランド化して いる農畜産物（含加工品）があると答えた農業集落 (以下,「ブランドある集落」と略す) の割合を零細 経営の多い西日本や農業地域別に算出したものであ るが，全国集計欄に示すようにブランドある集落の 割合が $23 \%$ となっている. 西日本で地域団体商標の 登録・出願実績が浮とんどなかった米は全農業集落 の $3 \%$, ブランドある集落の $16 \%$, 野菜, 果実もそ れぞれ全農業集落数の $7 \%$ ，5\%，ブランドある集落 の 30\%, 29\%を占め, 地域団体商標登録・出願実績 に比べて基幹作物が存在感を示している. 地域別に は, 条件不利と言われる中間農業地域は $25 \%$, 山間 農業地域は $24 \%$ の割合を示し, 都市地域の $15 \%$ を大 きく上回り, 平地農業地域に比べても $3 \sim 4 \%$ の差 しかない. 中山間地域の方が優位性を示す作目もあ る. 農畜産物ブランド形成の可能性に関して, 中山 間地域は決して条件不利地域とは言えない.

反対に注目すべきは, 約 8 割の農業集落がブラン ド農畜産物の認知を示していないという点である. この結果を素直に受け止めるならば，ブランド形成 
表 1. ブランド化している農畜産物があると認識している農業集落の割合

\begin{tabular}{|c|c|c|c|c|c|c|c|c|}
\hline \multirow[b]{2}{*}{ 区分 } & \multirow{2}{*}{$\begin{array}{c}\text { 農業集落 } \\
\text { 総数 }\end{array}$} & \multirow{2}{*}{$\begin{array}{c}\text { 農畜産物をブ } \\
\text { ランド化してい } \\
\text { る農業集落 }\end{array}$} & \multicolumn{6}{|c|}{ ブランドある集落数を 100 とした場合の作目別集落構成比（\%) } \\
\hline & & & 米 & $\begin{array}{c}\text { 麦・雑穀・ } \\
\text { 芋・豆 }\end{array}$ & 野菜類 & 果樹類 & 畜産物 & その他 \\
\hline 1. 全国計 & 135,163 & 23.1 & 23.9 & 6.0 & 32.5 & 22.6 & 5.8 & 9.3 \\
\hline 2. 西日本計 & 62,964 & 21.7 & 16.4 & 7.4 & 30.0 & 28.8 & 7.0 & 10.4 \\
\hline 近畿 & 11,347 & 23.3 & 5.5 & 9.3 & 40.6 & 26.0 & 7.7 & 10.9 \\
\hline 中国 & 18,589 & 15.3 & 16.3 & 9.3 & 27.3 & 38.6 & 1.9 & 6.7 \\
\hline 四国 & 10,406 & 21.0 & 16.6 & 5.3 & 29.1 & 32.7 & 1.5 & 14.9 \\
\hline 九州 & 22,622 & 26.3 & 21.2 & 6.4 & 27.0 & 23.9 & 11.2 & 10.3 \\
\hline 3. 農業地域別 & & & & & & & & \\
\hline 都市的地域 & 31,588 & 14.9 & 13.0 & 4.2 & 46.6 & 28.3 & 1.7 & 6.3 \\
\hline 平地農業地域 & 36,443 & 28.0 & 27.0 & 5.0 & 40.9 & 16.6 & 5.7 & 4.8 \\
\hline 中間農業地域 & 43,396 & 24.5 & 27.0 & 7.4 & 21.8 & 28.5 & 6.8 & 8.5 \\
\hline 山間農業地域 & 23,736 & 23.9 & 21.5 & 6.6 & 25.5 & 17.6 & 7.5 & 21.4 \\
\hline
\end{tabular}

注 : 2000 年農業センサスにより筆者整理.「その他」には, 工芸作物, 山菜, きのこ類, その他が含まれる.

の取組は約 2 割の農村地域または関係産地に何らか の活性化効果をもたらす可能性があると考えられる 一方, 残り約 8 割の関連産地・地域の活性化をどう 図るかが課題として十分認識されねばならない.こ れは上述のように, 農業・農村活性化における地域 ブランドの可能性と限界を同時に示したものと言え る. 中山間地域は他地域に遜色ないブランド形成の 可能性を示しているにもかかわらず, 人口減少, 高 齢化, 地域社会の機能不全に陥っている集落が圧倒 的に多いことも ${ }^{3)}$, 地域ブランドの限界を示すもの にほかならない.「WG 報告」でいう「地域の農林業 の発展」,「地域経済の活性化」,「地域コミュニティの 再生」に近付くためには, 地域ブランド以外の取組を 含めて多様な活性化方策を構想する必要がある.

（2）地域ブランド形成に向けた自治体の新たな動き ブランド形成の取組がどこまで農業, 農村地域に 影響を与えているかを検証するもう 1 つの手法とし て，地域ブランド形成に向けた自治体の動きを捉え ることである. 以上にみた地域ブランド登録件数の 都道府県間較差, 登録と出願件数の差, 登録 - 出願 実績と農業集落段階のブランド認知度との差等の点 はいずれもブランド形成拡大の可能性を示している が, こうした可能性が地域の取組としてどのように 現れているのか. 地域ブランドへの期待の大きさま たはブランド形成の動きと地域との関係を知る上で 把握すべき点である.

表 2 は, 2007, 2008 年度総務省「頑張る地方応援
プログラム」に応募したプロジェクトの中で,「ブラ ンド」コンセプトが入ったプロジェクト（以下，「ブ ランド関連 $\mathrm{P} 」$ と略す）を抽出した結果をまとめた ものである. この事業は年間 2,700 億円の交付税措 置（2007）を受けた地域活性化の目玉対策で，地方 の知恵を結集するものまたは地域活性化におけるブ ランド関連取組の位置付けを示すものとして注目さ れる。同表で明らかなように，ほぼすべての市町村 は同プログラムを申請している. 2008 年ブランド関 連 P に申請した市町村は全市町村の $23 \%$ を占め, 初 年度に比べて申請市町村数も申請件数も $1 \sim 2$ 割増 えている.

農林水産・食品関連プロジェクトは 2 力年ともブラ ンド関連 P の 8 割を占める. 約 1 割に上る観光・交 流関連プロジェクトの中でも農林水産・食品関連のも のが含まれているため, 地域団体商標の出願・登録実 績に比べて農林水産業の存在感は極めて大きい.

しかし，ここでも地域間の違いが顕著に現れてい る. 多少の例外もあろうが, ブランド関連 P の市町 村申請率をみると，東京・大阪といった大都市圏の 都府県浪ど低く，東北，北陸，四国，九州等農業地 域ほど高い傾向が見られる。地域ブランドへの期待 の大きさは同時に, 地域農業や地域経済に対する危 機感の強さを表しているように思われる.

表 1 でみたブランドある農業集落の割合と同じよ うに，約 8 割の市町村が地域ブランドを重点施策に 挙げていない. ブランド形成を目指している地域の 
表 2.「頑張る地方応援プログラム」におけるブランド関連プロジェクトの申請状況

\begin{tabular}{|c|c|c|}
\hline 区分 & 2007 & 2008 \\
\hline \multicolumn{3}{|l|}{ 1. 概要 } \\
\hline 申請市町村総数 & 1,762 & 1,795 \\
\hline 「ブランド」関連 P 該当市町村数 & 357 & 415 \\
\hline 「ブランド」関連 P の件数 & 382 & 450 \\
\hline \multicolumn{3}{|l|}{ 2. ブランド関連 P の内容構成 } \\
\hline 農水産・食品関連 & 86.1 & 83.6 \\
\hline 観光・交流関連 & 9.7 & 9.6 \\
\hline 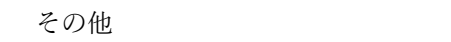 & 4.2 & 6.9 \\
\hline 3. ブランド関連 P 申請市町村の割合 & 20.3 & 23.1 \\
\hline うち：10\%以下都道府県 & $\begin{array}{l}\text { 栃木, 群馬, 埼玉, 千葉, 東京, 神奈川, } \\
\text { 愛知, 三重, 滋賀, 京都, 大阪, 香川 }\end{array}$ & $\begin{array}{l}\text { 群馬, 埼玉, 千葉, 東京, 神奈川, 愛知, } \\
\text { 大阪 }\end{array}$ \\
\hline $11 ２ 0 \%$ 都道府県 & $\begin{array}{l}\text { 新潟, 富山, 石川, 山梨, 岐阜, 静岡, } \\
\text { 兵庫, 奈良, 和歌山, 岡山, 山口, 福岡, } \\
\text { 熊本 }\end{array}$ & $\begin{array}{l}\text { 宮城, 栃木, 新潟, 静岡, 三重, 滋賀, } \\
\text { 京都, 和歌山, 岡山, 香川, 福岡, 熊本, } \\
\text { 沖縄 }\end{array}$ \\
\hline $21 ＼mathrm{~ 30 \% 都 道 府 県 ~}$ & $\begin{array}{l}\text { 岩手, 宮城, 福島, 茨城, 長野, 広島, } \\
\text { 德島, 愛媛, 高知, 長崎, 沖縄 }\end{array}$ & $\begin{array}{l}\text { 福島, 茨城, 富山, 石川, 山梨, 長野, } \\
\text { 岐阜, 兵庫, 奈良, 山口, 徳島, 高知, } \\
\text { 佐賀, 宮崎 }\end{array}$ \\
\hline $31 ４ 0 \%$ 都道府県 & $\begin{array}{l}\text { 北海道, 秋田, 山形, 福井, 鳥取, 佐賀, } \\
\text { 大分, 宮崎, 鹿児島 }\end{array}$ & $\begin{array}{l}\text { 北海道, 青森, 岩手, 山形, 広島, 愛媛, } \\
\text { 長崎, 鹿児島 }\end{array}$ \\
\hline 41\%以上都道府県 & 青森, 島根 & 秋田, 福井, 鳥取, 島根, 大分 \\
\hline
\end{tabular}

注 : 総務省「頑張る地方応援プログラム」市町村別個表一覧表により筆者が取りまとめたものである.

努力を如何に形にしていくかが重要であると同時 に，ブランド形成以外地域活性化手法の構想も不可 欠なのである.

\section{（3）基幹作目のブランド確立が地域農業に与える} 影響〜愛媛県西宇和地域を事例に〜

以上では地域ブランドの可能性と限界を形態学的 に考察してきたが, ここではさらに, 基幹作物のブ ランド確立が地域農業にどのような影響を与えてい るかを, 温州みかんの名産地として知られる愛媛県 西宇和地域を事例に具体的に検証する. 同地域では 「西宇和みかん」,「真穴みかん」が地域団体商標に登 録されている. 愛媛県「『愛』あるブランド産品」認 定制度により認定された 45 柑橘ブランドのうち, 24 品目が集積する地域でもある.

図 3 は, 1995 年以降同地域における温州みかん の単価変化を全国, 県平均との比較において示した ものである. 全国平均に比べて西宇和の単価は, 年 によって最低 $4 \%$, 最高 $28 \%$ 高く, 明白な価格優位 性でブランド効果を示している. しかし, 対県平均 は3〜8\%の価格プレミアムにとどまっているため, 対全国平均の価格優位性は西宇和というよりも, 主 としてみかん王国愛媛県の優位性を示していると

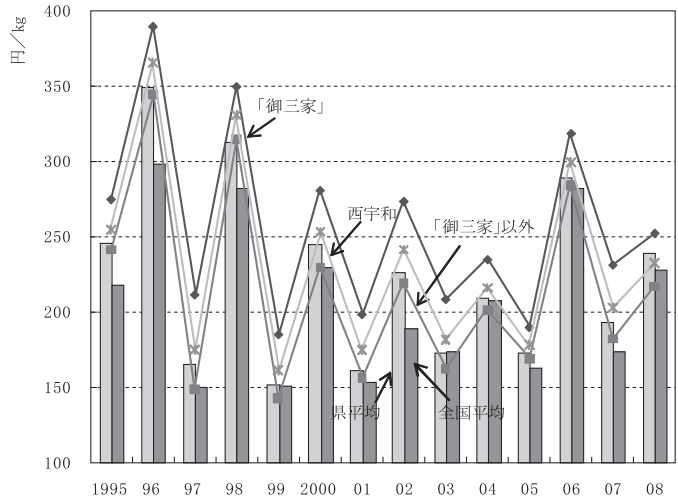

図 3. 西宇和の温州みかん価格 : 愛媛県および全国 平均との比較

注 : JA 西宇和および県関係部局資料により作成.

言える.

ところが, 比較の範囲を温州みかん「御三家」と 呼ばれる川上，真穴，日の丸 3 産地に絞ってみると， 違う側面が見えてくる. 対全国平均で $13 \sim 41 \%$ の 価格優位性を示すだけでなく，対県平均でも 10 $28 \%$ の価格差を付けている. 西宇和対全国・対県平 均の価格優位性とも「御三家」に大きく依存してい 
表 3. 温州みかん銘柄産地八幡浜市の動き〜愛媛県との比較において〜

\begin{tabular}{|c|c|c|c|c|c|c|}
\hline \multirow{2}{*}{ 区分 } & \multicolumn{3}{|c|}{ 旧八幡浜市 } & \multicolumn{3}{|c|}{ 愛媛県 } \\
\hline & 1995 & 2005 & $05 / 95$ & 1995 & 2005 & $05 / 95$ \\
\hline \multicolumn{7}{|l|}{ 1. 農業経営主体 } \\
\hline 販売農家数 & 1,761 & 1,499 & 85.1 & 51,072 & 36,950 & 72.3 \\
\hline 主業農家 & 1,065 & 809 & 76.0 & 14,789 & 8,614 & 58.2 \\
\hline うち：65 歳未満 & 989 & 765 & 77.4 & 12,666 & 7,437 & 58.7 \\
\hline 準主業農家 & 372 & 264 & 71.0 & 12,718 & 7,417 & 58.3 \\
\hline うち：65 歳未満 & 201 & 138 & 68.7 & 4,822 & 2,709 & 56.2 \\
\hline 副業的農家 & 324 & 426 & 131.5 & 23,556 & 20,919 & 88.8 \\
\hline \multicolumn{7}{|l|}{ 2. 農地資源 } \\
\hline 経営耕地面積 & 2,090 & 2,030 & 97.1 & 48,562 & 37,169 & 76.5 \\
\hline 田 & 34 & 27 & 79.4 & 21,066 & 17,039 & 80.9 \\
\hline 畑 & 28 & 22 & 78.6 & 4,338 & 3,177 & 73.2 \\
\hline 樹園地 & 2,028 & 1,982 & 97.7 & 23,158 & 16,954 & 73.2 \\
\hline 耕作放棄農家率 & 7 & 16 & 187.2 & 26 & 48 & 135.9 \\
\hline 耕作放棄面積率 & 2 & 8 & 478.8 & 8 & 26 & 261.3 \\
\hline \multicolumn{7}{|l|}{ 3. 柑橘生産 } \\
\hline 柑橘類出荷量 & 45,801 & 45,248 & 98.8 & 360,070 & 272,250 & 75.6 \\
\hline うち：温州みかん & 38,200 & 39,700 & 103.9 & 208,910 & 154,500 & 74.0 \\
\hline \multicolumn{7}{|l|}{ 4. 農業総生産 } \\
\hline 農業総生産 & 985 & 964 & 97.9 & 10,923 & 7,800 & 71.4 \\
\hline
\end{tabular}

るのである. こうした価格差は年によって大きく変 動するものの, 明確な縮小傾向も拡大傾向も示して いない．産地ブランドを確立した地域は長期にわ たって価格プレミアムを享受し ${ }^{4 ）}$, 卓越したブラン ド効果を示している.

ブランド効果は価格面に限らず, 農産物の販路確 保, 農地資源保全, 農業担い手の確保等多方面に及 んでいる. 表 3 は, 柑桶類「『愛』あるブランド産 品」の $44 \%$, 温州みかん「御三家」を擁する旧八幡 浜市農業の動きを県平均との比較において示したも のである. 1995 年以降の 10 年間で, 県全体として 主業農家は $42 \%$, 樹園地は $27 \%$, 柑橘出荷量は $24 \%$ と大きく減少したのに対して, 八幡浜市は樹園地, 柑橘出荷量, 農業総生産ともほとんど減少せず, 主 業農家の減少率も県平均より $18 \%$ 低い. 基幹作物の 産地ブランド確立は地域農業の保全に大きく寄与し ているのである.

しかし，この全国トップ級の名産地も困難な諸問 題を抱えている. 1 つは, 「御三家」と他共選との価 格差で示される域内産地間格差である. 比較対象期
間において「御三家」以外地域の単価は県平均を 2 〜 10\%,「御三家」を $10 \sim 30 \%$ 下回り, 市場評価の 差が歴然としている（図 3)。半島地域を中心に園地 荒廃も進んでいる。 これらの産地をどう活性化する かが地域にとって重要な課題である。もう 1 つは, みかん価格不安定の影響である. 1995 年以降の対前 年度価格比をみると，上げ幅で最大 1.9 倍，下げ幅 で最大 $52 \%$ を記録している. 単価が下がるたびに不 本意な加工向けは大量に発生し, 農業総生産も農家 所得も激減するなど, みかんの名産地でありながら みかん市場に翻弄されてきたのである. 3 つ目は, 農 業従事者の高齢化と後継者減少である. 県平均に比 べて農業後継者が比較的多く確保されているもの の, 1995 年以降の 10 年間で 65 歳未満農業従事者の いる農家は，主業・準主業合わせて $24 \%$ 減少してい る (表 3). この傾向が続けば, 産地ブランド力の維 持向上や地域農業に影響が出る可能性もあろう.

以上の考察により地域ブランドの可能性と限界に ついて幾つかの結果を得たが，それが同時にこれか らの産地づくり, 農業・農村の活性化を図っていく 
上で検討されねばならない課題を示唆するものでも ある。つまり，(1)地域ブランド形成の取組は「食」 と「農」の振興においてすでに一定の実績を上げ, いまなお増加傾向にある点から, 各地の取組を成功 させるために先行する名産地からどのような示唆が 得られるかをみる必要がある. (2)ブランドの発掘育 成に努力している産地やブランドの形成が困難と見 られる産地がどのような課題を抱え，どのような可 能性を有し，生産者がどのような努力を試み，何を 望んでいるかなどの点も, 地域ブランドを持たない 産地の実態解明や活性化の方向性を探る意味におい て把握しなければならない課題である. (3)ブランド 農畜産物を持っていない農業集落, ブランド形成を 地域活性化の重点施策に挙げていない市町村とも 8 割に上り, これらの地域の活性化がどのような形で 行われ，または行われようとしているかについても， 複合的産地づくり・地域づくりの視点から明確にし なければならない.これらの点を突き詰めていけば, ブランド形成が困難な産地の活性化戦略とは何かに 辿り着くことが可能であろう.

\section{3. 産地・地域活性化に向けた取組}

\section{（1）いま，産地で何が起き，何を求めているか}

以上の考察で抽出した課題(1)と(2)に対して, 前節 でも取り上げた愛媛県西宇和地域, 同じ愛媛県南予 地域にある G 産地, $\mathrm{Y}$ 産地 $\mathrm{K}$ 地区を事例に検証する. 3 つの事例は，地域ブランドとの関連性からそれぞ れ全国トップ級の名産地，ブランド形成の取組が始 まったばかりのブランド発掘育成中産地，そして無 名産地として位置付けられる. 地域範囲は, 多数の 共選を擁する広域複合産地, 産地 (共選), 産地の細 胞となる村に当たる. K 地区を考察の対象にした理 由は, 西宇和事例でみた地域内格差のように, 産地 活性化問題を考えるに当たって産地に包摂される地 域社会にも目を向け效ばならないためである。

《事例 1 : 名産地西宇和の示唆》 前節でみたよう に，旧八幡浜市を中心とする西宇和は名産地として 実績を上げつつも, 域内産地間格差, みかん価格の 不安定, 農業従事者の高齢化と後継者減少, 「御三 家」以外地域園地荒廃の進行等難題を抱え, 名産地 の強さと一般相滳産地に見られる構造的な弱さを併 せ持っている.これらの点は JA 組合員への意向調査 結果にも現れている．44\%の回答者は農業後継者の
見込みがなく, $29 \%$ の回答者は 5 年後「経営面積の 縮小」，そのうちの $42 \%$ ぞ廃園」を考えている ${ }^{5)}$. この現状を関係者は危機と受け止め, 所得確保と後 継者育成を中心にブランド力の向上を図っている.

そのための生産対策として JA 西宇和は, (1)光セン サー選果に対応したマルチ栽培の効果的利用による 北向き園地の条件改善と高品質果実生産，(2)老木・ 不良系統の更新と奨励品種の拡大, (3)労働負担軽減 のための園内作業道設置, (4)樹冠上部摘果・後期重 点摘果技術の徹底, (5)農地集積促進による耕作放棄 防止，(6)「見本樹」等情報交換の場の設置による産 地担い手育成等を共選ごとに策定し推進している. 販売対策としては，隔年結果の改善，厳選出荷体制 の確立, 個性化商材の拡大等商品力強化策と, 無登 録農薬の不使用と農薬安全使用，栽培履歴記帳の義 務化等安全安心対策を進めている. 園地荒廃が進行 している半島地域では，これらのほか高齢化対策と して「1 園地 1 品種」高品質・省力化栽培体系の確 立, 農地貸借・受委託等農地流動化推進による優良 農地の確保，規模拡大に合わせた園地条件整備，鳥 獣対策等が進められている.

これらの対策は産地に変化をもたらしていること を，品種更新の取組を通してみることができる，JA 西宇和の出荷実績によれば，1995～2008 年期間に おいて温州みかんは約 1 割，伊予かんと夏みかんは それぞれ半減したのに対して, 優良晚相の清見は 1.6 倍，不知火は 7 倍の伸びを示している。 しかし，共 選によって大きく異なる。「御三家」では晚相種が出 荷量の $2 \sim 3 \%$ （2008 年）に止まり，温州みかんを 主軸とする品種構成を維持しているのに対し, それ 以外共選では優良晚柑類が出荷量の 2 割に達し, 不 知火の場合は出荷農家数も 2 倍増の躍進ぶりを示し ている．市場評価の高い優良晚柑作の拡大は「御三 家」以外共選の存在感を高め, 産地全体のブランド 力向上と出荷安定に寄与している. 品種更新を軸と した新興ブランドづくりの取組が伝統産地に新しい 可能性をもたらしている.

西宇和取組の特徵は，徹底した市場（消費者）重 視，計画出荷，共選ごとの条件に見合った生産・販 売対策による収入確保の 3 点に集約される. 産地活 性化のキー・ファクターとされる後継者確保の条件 として関係者は, 2.5 人の労㗢力, 1.5 ha 成園経営 で年間 750 万円の販売収入もしくは 500 万円の所得 
確保を挙げている.これらの点は名産地ゆえではな く, ブランド発掘育成中の産地, ブランド力によら ない産地活性化の取組にも示唆を与えることは, G 産地, $\mathrm{K}$ 地区の事例や次項で述べる地域活性化の取 組により示されている.

《事例 2 : ブランド発掘中 $\mathrm{G}$ 産地の実態と可能性》 $\mathrm{G}$ 産地は県全体で推進する「愛」ある県産品づくり を行っているが，産地を代表するほどのブランド 産品はない. 1995 年以降の 10 年間で, 販売農家は $35 \%$, 柑桶作農家は $51 \%$, 果樹園面積は 49\%減少し ている、いずれも県平均を上回っており, 園地荒廃 進行の最前線と言っても過言ではない.

西宇和と決定的な違いは何かについて, 関係者は 次の点を挙げている. (1)農道が悪い. (2)スプリンク ラーがなく, 水やりや防除作業が重労働になる. (3) 日照不足の北向き園地が多い. (4)主力品種が絞られ ず多品種栽培となっている. (5) 1 ha 未満の小規模農 家が多い. (6)強力な共選リーダーがいない. (7)若い 後継者が少なく兼業率が高い. これらの点はブラン ド産地の形成を困難にしているというが，県内相杼 産地でよく見られる課題でもある.

ところが，この産地はもうどうにもならず，自然 崩壞を待つしかないと言えばそうでもない．その理 由は 3 つる. 1 つ, 産地内条件は均一ではなく, 条件のよいところで農家が残っている.もう1つは, 農地を荒らしたくない思いを持つ後継者がかなりい る. 彼らは売れるものづくりに意欲的であり，優良 品種の導入, 老木園の改植, 園地拡大を積極的に行っ ている. 生活ができれば農業ほどよい職業はないと 豪語する者もいる. 3 つ目は, 町内や近隣市町村に 勤め, 定年前または定年後農業に回帰してくる跡継 ぎもかなりいる，主婦・嫁たちも農業を支える大き な力になっている. 産地がなくならない理由は, そ の地域に住む人々の暮らしがそこにあるからであ る.

ブランドづくりの取組は始まったばかりである. 補 助事業を受けて県や JA が薦める奨励品種を試し, 地 域条件に適した優良品種体系の選別が進行中である. そのため, 有能な農家ほど価格変動のリスクを分散す るため多品種栽培を行っている. 育成中ブランドの販 売実績はまだ出荷量の $2 \%$ （2008 年）に満たないが, 東京市場で早生・中生種は $\mathrm{kg}$ 当たり $500 \sim 600$ 円, 晚 柑は 1,000 円ほどの高值が付く評判である. 今後, 出
荷量を増やし, 農家の所得向上につなげたいとしてい る. 当面の課題としては優良品種体系の確立, 北向き 園地におけるマルチ栽培の導入, 樹冠上部摘果・後期 重点摘果技術の徹底による隔年結果の改善, 中長期的 課題としては水源条件の確保, 軽トラックが入れる農 道造成等園地条件の整備を挙げている. これらの条件 なくして優良系統への転換が困難だという. 条件こそ 違うものの, 取り組んでいることや考えていることは 西宇和とあまり変わらない.

G 産地は現在, 414販売農家で312 haの経営耕地を 営んでいる. 販売農家のうち, 65 才未満農業専従者 のいる農家は 115 戸，同居農業後継者のいる農家は 98 戸ある. これを耕地面積と付け合わせてみると, 1戸あたり面積は前者で 2.71 ha, 後者で 3.18 ha と なる。果樹園のみだと，それぞれ 1.50 ha, 1.77 ha となる。，今後，限界園地を中心に廃園はさらに進む と予想されるが，仮にすべての園地を後継者に集積 させたとしても，この程度の経営規模にしかならな い.これらの数值で明らかなように, 園地荒廃進行 の最前線にある同地域でさえ，農地を耕すに足りる くらいの農業後継者が残っている．関係者は「農地 集積は可能だが，問題は人がいるかどうか」としつ つも,「所得さえ確保できれば農家はまだまだ頑張れ る」とも言う. 産地の行方は経営改善の可能性と所 得次第ということであろう.

《事例 3 ：産地に包摂される $\mathbf{K}$ 地区の現実と可能性》 $\mathrm{K}$ 地区は現在, 50 世帯が生活する沿海部中山間村で ある. みかんと少量のびわしかない相樀専作村では あるが，同地区が所在する合併前の旧行政区域を含 め, 名産地としての名声がない. 最近 2 年間の柑樀 単価をみると, 地区内最優秀農家でさえ所属する農 協の平均単価を下回り, 名産地の象徵とも言える価 格プレミアムとは無縁である.

地区の概要は表 4 に示している. 50 世帯中 23 世 帯は相滳専作農家で, 18.2 ha の園地を営んでいる. そのうち, 世帯主年齢 65 歳以上世帯が 19 世帯あり, 「高齢化で異質な村に変貌した」と言われている. 西 宇和でみた高齢化進行や $\mathrm{G}$ 産地で特に強調されてい る「人」の問題は, 産地に包摂されるこの末端地区 でより先鋭に現れている.

しかし, 柑樀産地として今後とも存続していくと 思わせる要素は幾つある. (1)世帯主 64 歳以下農業者 4 世帯（タイプ(1) は強い農業継続意思を持ってい 
表 4. K 地区の農業と暮らしの構造

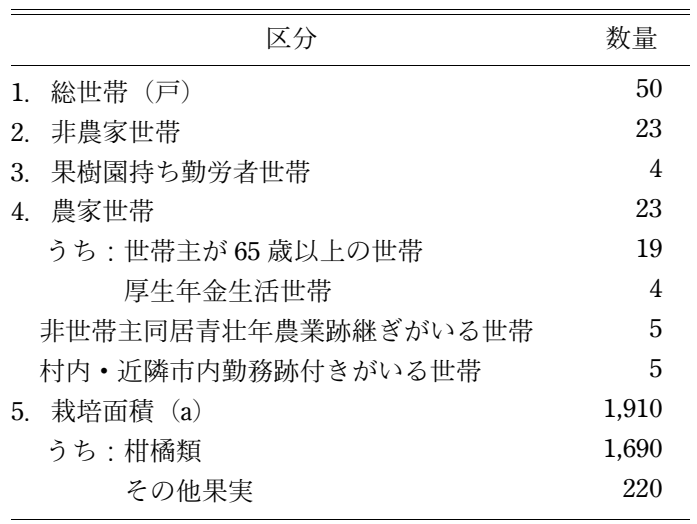

注 : 1) 出所 : 筆者聞き取りと農家記入.

2)「その他果実」はほとんど枇杷.

る. (2)この 4 世帯のほか世帯主と同居している 40 〜 50 代農業者（タイプ(2)）が 5 人おり, 今後柑樀作経 営を受け継ぐ可能性が高い. (3)村内・市内に動く 30 〜 50 代の潜在的農業後継者を持つ世帯（タイプ(3) も 5 戸ある. 農地面積をタイプ(1)と(2)の 9 世帯で割 ると2. 12 ha, タイプ(1)〜(3) 14世帯で割ると1. 36 ha になる. G 産地同様, 後継者不足と言われながら, 農 地との関係から見れば十分なほど温存している.

ほとんどのミカン園は急傾斜地にあり, 水源条件 未整備園地も多いため恵まれた条件ではない. しか し, 現役の農業者は柑樀作経営に強い意欲を持って いる. タイプ(1) 1 人で, レモンを含む 10 品目, 1.5 ha の柑樀作を営んでいる A 氏は, 次のような「我が家の 経営改善目標」を披露してくれた。 (1)南柑 20 号, 河 内晚柑の成園化で生産量を 10\%増加させる. (2)マル チ栽培を増やし, ネット販売を昨年の約 100 万円か らさらに拡大する. (3)河内晚柑, 文旦の薬害解消と 品質向上を進める. (4)せとか, ネーブル, レモンの 栽培面積をさらに拡大する。，一方で県・農協が進め る果樹産地の構造改革等については, 冷めた見方を 示している. 推奨品種「まりひめ」導入の失敗例を 引き出しながら A 氏は, どの品種・品目を作るかは 生産者に任せるべき問題であり, 農家のやることに 手を出すよりも生産者が望んでいる水源・園地条件 の改善や所得安定に力を入れるべきだと指摘する.

$\mathrm{A}$ 氏は 8 人の大家族で, 収入は祖母・父母の年金収 入と 400 万円程度の柑橘販売収入のみである. 強い 営農継続意思を持つ理由は家族の暮らしを支える手
段として相滳作しかなく，なおかつ努力すれば収入 改善の見込みがあるとみているからである。これは 僅かな国民年金収入しかない他の農家にも言えるこ とで，農地集積を長期化させる要因にもなる.

以上の事例考察から見えてきた点は 3 つある. 第 1 に, 各地域で条件の違いはあるものの, 農家が取 り組んでいることや考えていることに大きな違いは ない. 我が家の経営を改善し, より豊かでより穏や かな暮らしを目指そうとしている点で共通してい る.これは言い換えれば，地域はまだ十分豊かでな いことを意味する. 第 2 に, 各地域とも経営改善や 産地活性化に向けて懸命な努力を行っており, なお かつ徐々に実績を上げ，継続していく意欲もある. 産地の行方は経営改善の可能性と所得次第と言え る. 第 3 に, G 産地, $\mathrm{K}$ 地区のような極めて困難な 地域でさえ強い営農意欲を持ち, 農地を耕すに足り るほどの農業後継者を残している。これらの点は産 地存続・活性化の内的条件と可能性を示すものであ り, 産地再生, 地域活性化にどう活かしていくかが 課題である.

\section{（2）産地存続を支える地域活性化要素}

3 つの調查地域で特に強調されたもう1つの点は, 人口減少や高齢化進行に伴う地域社会の活力低下で あり，産地を存続させるためにも地域を活性化しな ければならないという点である. そのため, 各地で どのような活性化手法が構想または実施されている かに強い関心を持っている. これは, 前節の考察で 抽出した課題(3)でもある.

全国各地で構想または実施されている地域活性化 手法を示したのが図 4 である. 2008 年度総務省「頑 張る地方応援プログラム」に応募した 1,795 市町村の 個票から「地域活性化」コンセプトが入ったプロジェ クトを抽出し取りまとめたものである.ここでも農林 水産物・食品のブランド化に関連したプロジェクトは 17\%を占め, 地域活性化の手法として有力視されてい るが, 注目すべきはむしろ, ブランドづくりのほかに も多くの活性化手法が構想または実施されている点 である. 3 つの特徵をみることができる.

1 つは，活性化手法の豊富さである，ブランド関 連 $\mathrm{P}$ を除いても 433 件に上り, 活性化知恵の宝山と 言ってょい，その中には，ブランド形成が困難な産 地にとって参考になるものも多数含まれていると思 われ, 地域条件に適したものを厳選し, 産地・地域 


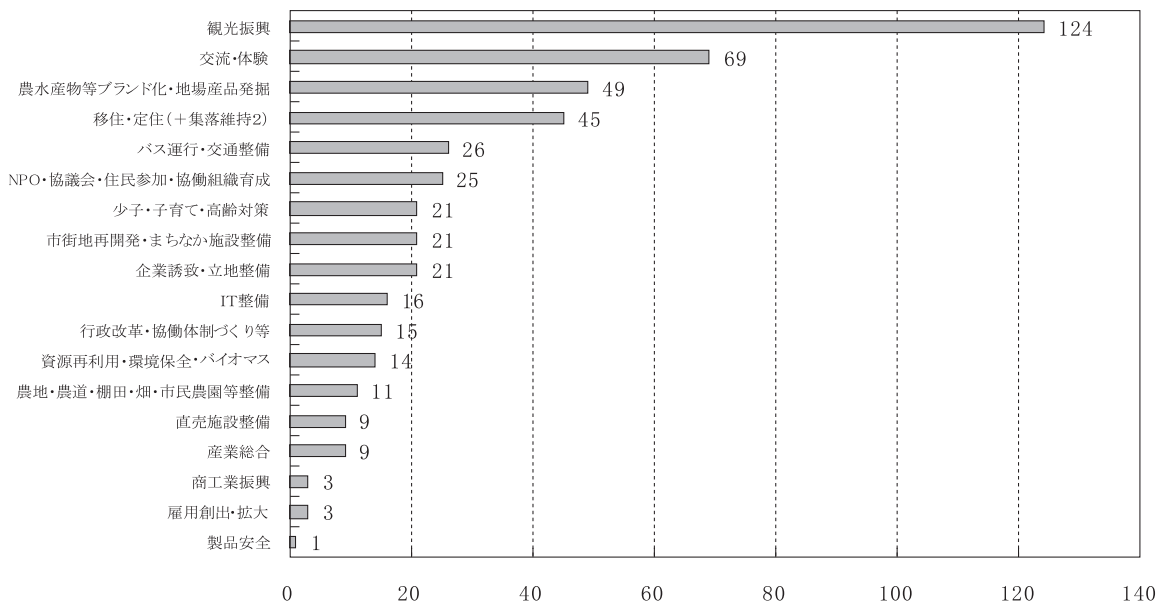

図 4. 地域活性化の要素構成

註 : 平成 20 年度総務省「頑張る地方応援プログラム」に応募した 1,795 市町村の個票一覧表において,「地域活性化」また は「地域の活性化」に該当するプロジェクトを抽出し，整理したものである。

活性化の取組に活かしていく工夫が求められる．自 治体だけでなく地域住民の知恵を引き出す努力も必 要であるが, 全体として知恵はもう十分であり，後 は選択と行動するのみと言えよう.

もう 1 つは, 上位数項目への集中度が極めて高い ことである.「観光振興」,「交流・体験」の 2 項目だ けで全件数の $40 \%$, ブランド関連 P を除く件数の 45 \%を占めている. この 2 項目は多くの地域で有力な 活性化手法と見られており, 注目に值する点である.

3 つ目は，担い手づくり関連項目が多いことであ る.「移住・定住」,「NPO・協議会・住民参加・協働 組織育成」「少子・子育て・高齢化対策」はむろん, 高齢化対策の一環として構想されたものが多い「バ ス運行・交通整備」もこれに該当し, 合わせて全体 の $24 \%$ 占める. 前項の 3 事例でみた人口減少や高 齢化進行に対する危機感を多くの地域が共有し, 対 応を急いでいるのである，対照的に，「企業誘致・立 地整備」関連は全体の $4 \%$ にとどまっている。これま でに実績を上げた地域は少なく，不況に伴う企業撤 退や雇用削減等もあり，こういった伝統的な地域開 発手法への期待が薄れてきていると推察される ${ }^{6}$.

観光・交流が注目される理由の 1 つは, 多くの効 果が期待されるからである. 農林水産省調査によれ ば 7)，農村に訪れて行いたいこととして，都市住民 側回答者の $76 \%$ が地域特産品や新鮮な農産物の購 入, $65 \%$ が郷土料理を味わうことと観光農園・牧場
利用，56\%が野外観察・自然散策，37\%がスポーツ 等レジャ一活動を挙げている。他方の農業者側は, 都市住民との交流に取り組みたいこととして $65 \% の$ 回答者が「特産品や農産物の販売」を挙げ，そのた めに「直売所の整備」(63\%)，「美しい村づくり」(60 $\%)$ ，「宿泊施設の整備」(54\%) 等を進めたいとして いる。需要側と供給側のニーズは一致し，農産物の 価值実現，農村資源の有効利用，農村社会の活性化 など多くの効果をもたらす可能性がある.

観光・交流が注目されるもう 1 つの理由は，それ を遂行するための条件が広範に整備され，なおかつ 確実に利用実績を上げ，波及効果も期待される点に ある. 2005 年農業センサスによれば, 関連施設を 持っている農業集落は全体の $11 \%$ を占め，合併後 1 市町村あたり 8 施設に達している．産地直売所を持 つ農業集落は 8,879 で最も多く, 市民農園，キャン プ場, 森林レクリエーション施設も多数整備され, 各種施設の年間利用者数は 2 億 3,000 万人に上って いる. 公的施設だけで年間約 1,500 億円の収入を上 げているとみられているが ${ }^{8)}$, 旅行関連支出や波及 効果を含むと少なくとも売上の 3 倍に相当する経済 効果を生んでいると推測される ${ }^{9)}$. この種の活動は, 豊かな地域社会と穏やかな暮らしにとって久かせな い要素になっている.

観光・交流とともに大きく注目されているのは農 産物直売施設である．産地直売所を持つ農業集落の 
表 5. 地域農業における農産物直売所の有効性

\begin{tabular}{lrcc}
\hline \hline \multicolumn{1}{c}{ 効果指標 } & からり & $\begin{array}{c}\text { さいさい } \\
\text { きてや }\end{array}$ & 伊都菜彩 \\
\hline 直売部門売上高 (千万円) & 47 & 139 & 210 \\
対地域農業産出額比\% & 14.6 & 12.2 & 23.7 \\
対地域生産農業所得比\% & 35.6 & 36.3 & 84.3 \\
会員（出荷生産者） & 426 & 1332 & 1082 \\
対地域農家数比\% & 18.4 & 20.0 & 79.0 \\
対地域販売農家数比\% & 29.5 & 32.4 & 97.1 \\
会員 1 人当たり売上 (万円) & 110 & 104 & 150
\end{tabular}

注：1）聞き取り調査による.

2)「からり」は直売部門，その他は総売上により計 算。また，「伊都菜彩」会員に漁業者が含まれる.

多さはこれを示しているが，図 4 の観光・交流，ブ

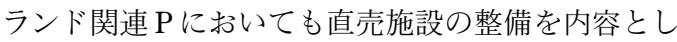
たものが多数含まれている. その効果は大型直売所 を中心に顕著に現れていることを表 5 の 3 事例が示 している 10). 1996 年に操業した愛媛県「内子町フ レッシュパークからり」は, 2007 年に 6 億 8,000 万 円を売上げている. 直売部門だけで町農業産出額 （2006 年，以下同じ）の 15\%, 生産農業所得の $36 \%$, 販売農家数の $30 \%$ をカバーする存在となっている.

開設 3 年目の愛媛県今治市「さいさいきてや」, 福 岡県前原市「伊都菜彩」も農家所得向上や地域活性 化の面で威力を発揮している. 2008 年「さいさいき てや」直売部門の売上は市農業産出額の $11 \%$, 生産 農業所得の $36 \%$ に相当する約 14 億円に達し, 出荷 会員数は販売農家数の $32 \%$ をカバーする.「伊都菜 彩」は，150万人を擁する福岡市に隣接する立地上 の強みもあって, 2008 年に同市農業産出額の $24 \%$, 生産農業所得の $84 \%$ に相当する 21 億円の売上を実 現し, 出荷会員数は販売農家・漁業者数の $97 \%$ を力 バーする.

優れたマーケティング力で明確な市場指向のブラ ンドづくりとは異なり, 直売施設の取組は地域で生 産されたあらゆる農産物を受け容れ, 消費者を地域 に呼び込む形で農業・農村の活性化を図ろうとして いる. 生産物も生産者も差別しない全員参加型の社 会装置として農産物流通の一役を担っている。その 効果と可能性も売上の大きさや伸び率のみで測られ るものではなく, 流通経費の節減と農家手取の増加 による富の再分配, 輸送距離の短縮による $\mathrm{CO}_{2}$ 削減, 女性・高齢者の社会参加等多方面に及んでいる. 市
場流通が低下する中で，農業・地域活性化における その重要性が益々大きくなると考えられる。しかし 同表にも見られるように，これらのメリットは地域 によって大きく異なる．都市に近い地域に大型施設 が集中し，中山間等不便な地域ほど小規模施設が多 (11). 西宇和のような大規模専作産地に向かないと ころは，その限界を端的に表していると言える。施 設の効果を十分発揮するためには，図 4 に示す他の 地域活性化手法と併用する工夫が必要である.

\section{4. 産地活性化の条件〜豊かな地域社会と穏やか な暮らしの形成に関する展望〜}

以上の考察で明らかなように, 産地も, 産地に包 摂される地域も，産地を抱える地域も大きく動いて いる. 高齢化, 後継者不足, 耕作放棄といったネガ ティブな方向へと突き進むだけでなく，地域資源に 立脚し，時の流れを汲み入れたブランドづくり，生 産条件整備やマーケティング努力，我が家の暮らし と経営改善, 産地ブランドによらない個性的で多様 な地域活性化手法の発掘など，難局打開と新たな可 能性をともに追求する革新的な動きも現れている. 前者を不活性化要素, 後者を活性化要素というなら ば, 産地活性化戦略とは, 活性化要素を育て実らせ, 不活性化要素を減らしていくほかない，そのための 条件も以上の文脈から示唆を与えられているが，4 点ほどまとめたい．

\section{（1）所得向上の阻害要因を取り除く生産条件整備の}

\section{推進}

西宇和で特に力を入れている園内作業道設置, $G$ 産地, $\mathrm{K}$ 地区で求めている水源条件改善や農道整備 等はもちろん, 図 4 に地域活性化要素として挙げて いる諸項目もこれに該当するものが多い．事例考察 でみたように，どの地域も農家の取り組んでいるこ とや考えていることがそう違わない，違うのは，置 かれている地域の生産条件であり，生産条件に規定 される取組の蓄積と直面する課題である。生産条件 の改善はこうした阻害要素を取り除き，生産者の所 得向上と産地存続・地域活性化につながるのである.

このように考えるならば，相樀産地で進めている 奨励品種・品目への改植, 高接, 小規模園地整備と いった果樹産地の構造改革は正しいように見える が，産地を活性化させる決定力になっているかと言 えば別問題である．新しい果樹産地対策に転換した 
2007 年以降愛媛県の実績をみると, 果樹園改植面積 は年 40 ha 程度で柑滳栽培面積の $0.2 \%$ に過ざない. 多くの農家が望んでいる園内作業道設置についても 補助事業の受益者は年 40 戸程度, 柑樀販売農家の 0. 03\%しかない，対策のインパクトはあまりにも小 さい. 構造改革で産地活性化を図るならば, 園地荒 廃の速度を上回るテンポで生産条件整備を進めねば ならない.

\section{（2）地域段階の所得創出}

産地ブランドを確立した西宇和では, 共選ごとに 生産・販売対策を立て, 所得確保と後継者育成を中 心にブランド力の向上を図っている. 後継者確保の 条件として 2.5 人の労働力, 1.5 ha 成園経営で年 750 万円の販売収入もしくは500 万円の所得確保を挙げ ている.

$\mathrm{G}$ 産地は厳しい条件の中で産地ブランドの発掘育 成に取り組み, 高品質みかんづくりで成果を上げつ つある.「所得さえ確保できれば農家はまだまだ頑張 れる」という言葉に象徵されるように, 所得確保は 産地再生努力を持続させるための原動力である.

$\mathrm{K}$ 地区では，最優秀農家でさえ西宇和でいう 500 万円所得に遠く及ばない. しかし G 産地同様, 営 農意欲があり, 農地を耕すに足りるくらいの後継者 を残している. 農業は暮らしを支えるための手段で あり, 頑張れば収入改善の見込みがあるとみている からである.

これらの点で明らかなように, 活性化要素も不活 性化要素も所得と深く関係しており ${ }^{12)}$, 所得確保は 産地活性化の基本なのである. 所得確保は生産者個 人の努力が大前提となるが, 産地段階の所得創出努 力も欠かせない．多方面に及ぶ複雑な問題ではある が，地域農業に大きな責任を持つ農協の事業を中心 に重要と思われる点を $3 つ$ 挙げてみよう.

1つ目は, 販売事業の建て直しによる収入確保であ る. 柑滳産地では, 農家と農協は専属利用契約で結 ばれ, 農家の収入は農協の販売事業に大きく依存し ている. 多くの調査によれば, 生産者は販売事業に 大きく期待する一方, 事業運営への満足度が必ずし も高くない ${ }^{13)}$. 西宇和と $\mathrm{G}$ 産地の違いとして強力な 共選が挙げられていることも，これを端的に示して いる. 市場外流通の拡大で農協主導の価格形成機能 が低下する一方, 需要喚起やマーケット開拓の面で 生産者の期待に応えられない場面が多かったからで

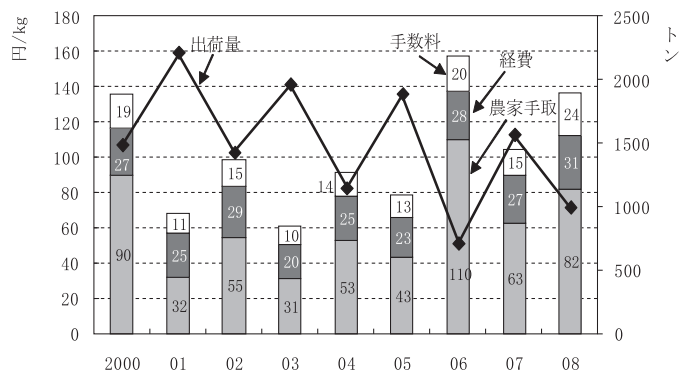

図 5. G 産地のみかん出荷量, 販売単価と支払い構成

ある．産地の存続・活性化を図るためには，農家の 収入に直結する販売事業の建て直しが不可欠であ り, 方向性も明確である. 共販の強みを活かしつつ, 卸売 - 小売, 食品加工, 飲食, 観光旅行等大口需要 者との契約販売網を構築し新しい地産他商の形を創 るとともに, 地産地消推進でローカルマーケットを 掘り起こし, 自らの手で市場を創っていくのである.

2 つ目は, 経費節減による生産者手取の確保であ る. 市場開拓の努力は農産物の供給過㮃という厚い 壁にぶつかるため限界があり，与えられた市場条件 の中で生産者の手取を如何に確保するかが重要な課 題である. 図 5 は, G 産地年度別みかんの出荷量, 販売単価およびその支払い構成を示している. 販売 単価は出荷量以上に激しく変動し著しい不安定性を 示す一方, 生産者手取は単価の低い年ほど低く 5 割 を下回る年もある. 生産者手取と経費単価・手数料 構成で明らかなように, 農家は農協以上に価格変動 のリスクを背負っている. これを当たり前と見る農 協関係者も多いが, 生産者の手取確保なくして産地 活性化はあり得ないという点から, 改善すべき課題 とみるべきである.

いま直売所や契約販売では, 販売額の 2 割程度を 手数料とするいわば「流通マージン 2 割相場」が形 成されつつある. 生産物の輸送距離や条件等によっ て流通経費が異なり，流通マージンを何割にしたら よいかが一概に言えるものではない.しかし，「流通 マージン 2 割相場」の形成という現実に目を向ける 必要がある. あらゆる面で経費節減の可能性を追求 するとともに, 費用負担のあり方を再考しなければ ならない. 検討すべき点として, 選果施設等農業施 設関連費用（減価償却費，利用料等）を主に施設利 用者の農家に負担させるのではなく，信用，共済を 
含めてすべての事業で分担し, 最終利益黒字の場合 は基本的に生産者負担をゼロにすることを提起した い. 信用事業も共済事業も農業者と無関係ではない. 「農」を基本とする農協の事業であるから一定の政策 恩恵を受けて成り立っている側面もあり ${ }^{14 ）}$, 農業施 設関連費用を農協の共通資本費用として負担する合 理的な根拠があると考える。農業関連施設負担費を 基本無料にして生産者手取を確保し，農協事業利用 率の向上と産地活性化を同時に図るのである。表 5 に挙げた「伊都菜彩」を運営する福岡県 JA 系島はす でに減価償却費ゼロ負担を実施しており, その経験 を一般化することが可能かどうかについて検討する 必要があるように思われる。

3 つ目は, 情報提供サービスの充実による経営改 善と所得向上である. G 産地の農家は, 産地ブラン ドの確立に必要な優良品種の選別, 品質向上, 収量 安定化に役立つ情報を求めている．K 地区やその周 辺地域では, 県・農協の推奖品種「まりひめ」導入 で失敗した農家がかなりあるという。糖度や単価の みを重視し, 収入を構成する歩留まりや収量の安定 性, 栽培条件等について十分な情報を与えなかった ためである.この種のことは $\mathrm{G}$ 産地, $\mathrm{K}$ 地区に限る ものではない，農協の広域合併を進めた結果，多く の地域で営農指導の粗放化が進み, それを補う有力 な手段として情報サービスの充実が求められてい る. 農業経営, 産地再生, 地域活性化に必要なすべ ての情報を厳選の上提供し, 現場における情報面で の劣位性を補完する情報システムを確立することに より生産者の経営改善努力をサポートするのであ る. そのためには, 農協自身も研究と情報力に優れ た組織にならねばならない。

\section{（3）生産者と産地段階の経営努力をバックアップ する経営所得対策の確立}

前節の事例考察で明らかになった重要な事実の 1 つは, $\mathrm{G}$ 産地, $\mathrm{K}$ 地区のような極めて困難な地域で さえ強い営農意欲を持ち, 農地を耕すに足りるくら いの農業後継者を残しているという点である. しか し彼らが農業で頑張れるかどうかは条件次第であ る. $\mathrm{K}$ 地区の例でいうと, 潜在的を含む農業後継者 をもつ 14 農家のうち, 柑橘作だけで生活できる 1. 5 ha 以上農家は 2 戸しかなく, 残り 12 農家は 70 a 〜 1 ha 程度の中規模農家である. 彼らに村の農地を 集積し規模拡大していく意欲と気力を持たせるため
には，上述した生産条件の整備や地域段階の所得創 出努力に加え, 頑張るほど所得が増え, 暮らしが楽 になるような環境を整えていく必要がある。新しい 果樹産地対策には，水田・畑作で実施しているよう な経営所得保障機能は含まない。価格安定機能も農 業団体主導の計画的な生産出荷と, 一時的な出荷集 中により発生する加工向け生果の費用の一部に対す る補助のみである。 こういう形で一定の価格安定機 能を果たしたとしても，制度が目指す「将来にわた る担い手の経営安定と所得確保」には程遠いもので ある. その改善策として, 直接所得支払い機能を有 する経営所得対策の導入が考えられる. 農地集積の 実績, 経営・環境効果等に比例して一定の直接所得 を交付する形で規模拡大，品質向上，販路開拓，費 用節約, 環境保全等真剣な経営努力にインセンティ ブを与え，産地担い手の育成につなげていく．

\section{（4）条件不利地域の定住促進と資源・環境保全}

西宇和のような名産地の一部を含めて不活性化要 素の多い条件不利地域では，以上の諸手法で解決で きない問題があり, このままでは産地・地域社会の 荒廃進行が止まらない．現在の中山間地直接支払い 制度は,「1 ha の団地要件」のような条件不利地域 対策らしくないところ，「遡及返還義務」のような乱 暴で冷たいところ, 生産条件の不利補正だけで暮ら しの視点が欠落しているところ，支払い対象や金額 の決定に現場の裁量が大きく不公平な結果を生むな ど，地域活性化に目立った効果を上げていない. 関 連する農地・水・環境保全向上対策も何となくやっ ている不急不要の感がある，産地・地域社会の荒廃 進行を食い止めるには, 速効性と恒久性を併せ持っ た制度の確立が必要であり，2つほど提案したい.

1 つは，国家公務員に支給する特地勤務手当等の ように生産・生活条件面で著しい不利性を持つ地域 に条件不利地域居住手当制度を創設することであ る. 中心居住地域への距離，集落の農地整備率，家 族構成のほか，農業や地域保全活動との関わり等を 考慮して特地勤務手当を下回らない水準の条件不利 地域居住手当を戸別に支給し，定住促進を行う.

もう 1 つは, 図 4 に挙げている諸活性化策を地域 住民自主選択の下で実施し, 資源・環境保全と地域 活性化を図ることである. 観光・交流活動への期待 が大きいことを踏まえ，従来のような公共事業だけ でなく，定住や観光・交流に寄与する美しい村づく 
りに力点を置くべきである. 美しい村づくり・地域 づくりで農村居住空間の資産価值を高め, それを保 有したい人や地域に訪れたい人を増やすことで地域 社会の永続を図っていく，具体策として，例えば, 「美しい村」「美しい町」を認証するような制度の導 入が考えられる.

以上に挙げた 4 つの中, 2 点目以外はいずれも財 源の裏付けが必要であるが, 条件は十分あるとみて よい. 2008 年度一般会計における農業予算額は 2 兆 6, 370 億円，これに追加予算，補正予算を加えると 約 3 兆円規模になる. 総務, 経済産業, 国土交通, 環境等省庁の関連予算や地方出資をさらに加える と, 少なくとも年間 $5 \sim 6$ 兆円の公的資金が農林水 産業に投入されている計算になる。他方では, 2007 年度農林水産総生産は 6 兆円弱である. この産出対 投入関係で明らかなように，農林水産業への財源投 入はほぼすべての農林水産物を買い取る水準に達し ている。これほどの大金を使っていても農業者が経 営に苦しみ, $\mathrm{G}$ 産地や $\mathrm{K}$ 地区農家が求めている水源 条件・園内作業道の整備すら遅々と進まないという のは理に叶わない，打金の使い方に問題があると考 える. 諸施策の整理・統合や関係省庁との連携も視 野に入れ，農業予算の大幅な組み替えを含む打金の 使い方を変えれば, 産地・地域活性化に結び付く政 策の遂行が可能となろう.

\section{5. むすび}

農産物市場で高級品が苦戦している今日的経済情 勢の下で, ブランドばかりで語っていられない現実 がある。しかしこういった取組で示される産地間・ 地域間の知恵比べは経営主体にインセンティブを与 え, 農業経営や産地に変革の契機をもたらす可能性 がある. 個性的で多様な地域ブランドづくりの実践 は，ブランド形成の困難な産地，ブランドによらな い地域づくりにも多くの示唆を与えよう。各地の取 組を成功させるためには, あらゆる努力を傾注すべ きである. 他方では, ブランドづくりで解決できる 問題が極めて限られているのもまた確かな現実であ り, 通常の農産物を作る生産者でも安心して農業経 営に従事できる環境を整える必要がある．容易なこ とではないが，本報告で示したようにそのための知 恵も条件もある。 これらの知恵と条件を地域活性化 に活かしていくに当たって, 産地・地域そのものよ
りもそこに生活する人々に目を向けることが肝要で ある。産地・地域社会の荒廃はその地域に住む人々 の暮らしの崩壊から始まり，その流れを断つための 活性化対策もまた，地域に住む人々の暮らしの再建 から着手しなければならない，産地主義，地域主義 から人の暮らしを大事にする人本主義への転換であ る.こうした転換は結果的に産地活性化をもたらし, 真に豊かで穏やかな地域社会の形成につながってい くと考えられる.

[付記 ]

本報告に $2007 \sim 08$ 年度卜ヨ夕財団研究助成「豊か な地域社会と穏やかな暮らしの成立条件に関する経済 生態学・社会生態学的研究」による研究成果の一部が 活かされていることを記して，感謝の意を表したい.

注 1) 特徵的な農産物とは, 全国平均に対して特化度が高く, 作付もしくは生産量上位部門を指している．地域団体 商標登録実績と合わせて, 資料の詳細は学会大会報告 要旨集報告論文を参照されたい.

2）日経リサーチ『2008 地域ブランド戦略サーベイ』（地 域総合評価編, 名産品編), 斎藤〔10], 本シンポの斉 藤, 青谷, 清水諸報告, および高橋〔14〕を併せて参 照されたい.

3）国土交通省国土計画局「国土形成計画作成のための集 落の状況に関する現況把握調査（図表編）」結果 (2007 年 8 月）はこの傾向を鮮明に示している.

4）この点については, やや違う見方を示している生源寺 〔13〕をも参照されたい.

5）以下に挙げる生産・販売対策と合わせて，八西地域農 業振興協議会「果樹産地構造改革計画」(2007 年 8 月) を参照されたい.

6）岡田 [9]を併せて参照されたい.

7）平成 12 年「都市と農村の交流に関する意識・意向につ いて」による.しかし，図 4 に挙げている観光・交流 とは都市農村交流に限るものでないことにも留意され たい.

8）(財）都市農山漁村交流活性化機構「主な公的グリー ン・ツーリズム関連施設における経済的・社会的活動 実績動向調査」（2004）を参照されたい.

9）国土交通省〔7〕によれば，国内観光は支出額の 2.27 倍に相当する生産波及効果, 1.22 倍に相当する付加価 值効果のほか, 就業者の $7.4 \%$ に相当する雇用効果を 生んでいる. 大江 〔11]は, この種の活動は現段階で 「社会的最適点より過小供給の状態にある」と指摘し, 今後の一層拡大の可能性を示唆している. 
10）直売施設の効果については池上〔4], 中安〔8〕の学会 報告, 農林水産省「農産物の直販・加工に関する意向 調査」(2001）,「地産地消に関する意識・意向調査結 果」(2007), および注 8) の調査等がある. 関連研究と して大江〔11]，霜浦・宮崎〔12〕を参照されたい，大 江は, 直売を観光交流活動「御三家」（p. 349）の1つ と位置付けている.

11）農林水産省「農業・農村の持続的な発展への取組みに 関する調査」（2004）を参照.

12）例えば, 農林水産省「農業経営の展開に関する意識・ 意向調査結果」(2003) において「農業を営む上の経営 問題」として $6 \sim 7$ 割の回答者が「農産物価格が不安 定」５割の回答者が「生産資材価格が高い」等農業所 得関連問題を挙げていること, 同年「近年まで農業を 営んでいた方への意向調査結果」に打いて農業経営の 困難さを感じた理由や経営を断念した理由として収入 要因を挙げた者が最も多かったことは, 不活性化要素 と農業所得の関係を明示している。 また,「農家のこせ がれ」が東京に出て働く理由として「実家は農家だが, 『農業では飯が食えないから東京へ出て働け』と言われ た」(同ネットワーク HP) ことも，この点を明快に示 しているように思われる.

13）販売事業については桂 〔6], 拙稿 [3]（第 3 章, 同補 論）も併せて参照されたい.

14）関連論考として神門〔2〕（第 3 章），青柳〔1]，小松 〔5]を参照されたい.

\section{引用文献}

〔1〕青柳 斉「JA バンクシステム下の系統信用事業の特質 と展望一主に事業収益の構造の分析から」, 小池恒男編 著『農協の存在意義と新しい展開方向一他律的改革へ の決別と新提言』，昭和堂，2008，pp. 167-193.

〔2〕神門善久『日本の食と農一危機の本質』, NTT 出版, 2006.

〔3〕胡柏『環境保全型農業の成立条件』，農林統計協 会, 2007.

〔4]池上甲一「農産物直売所を中心とする地産地消の新段 階一グローバル経済下におけるマーケティングの方向 を考える一」、農林業問題研究』第 38 巻第 4 号 (2003), pp. $47-48$.

〔5〕 小松泰信「事業基盤の構造変化に対応した共済事業戦 略」, 上掲〔1], pp. 194-208.

〔6〕桂 瑛一「経済事業改革の評価と改革課題」, 上掲〔1], pp. 119-134.

[7]国土交通省総合政策局旅行振興課『旅行・観光産業の 経済効果に関する調查研究VI：2005 年度旅行・観光消 費動向調査結果と経済効果の推計』, 2006.

〔8〕中安 章「都市・農村交流による農産物流通の展開」, 『農林業問題研究』第 34 巻第 3 号 (1998), pp. 11-19.

[9]岡田知弘「地域農業の発展方向と農業の役割」、『農林 業問題研究』第 32 巻第 3 号 (1996), pp. 10-19.

〔10〕斎藤 修編著『地域ブランドの戦略と管理一日本と韓 国／米から水産品まで一』，農文協， 2008.

〔11〕大江靖雄「多角的資源利用と農村経済の持続性」, 『農 林業問題研究』第 43 巻第 4 号 (2008), pp. 13-22.

〔12〕霜浦森平・宮崎 猛「内発的発展に関する産業連関分 析一京都美山町における地域経営型都市農村交流産業 を事例として一」, 『農林業問題研究』第 38 巻第 1 号 (2002), pp. 13-24.

〔13〕生源寺眞一「条件不利地域農業の問題構造と政策課 題」,『農林業問題研究』第 32 巻第 3 号 (1996), pp. 2-9.

〔14〕『高橋正郎論文集 I 農業の経営と地域マネジメン 卜』, 農林統計協会, 2002 . 